\title{
Analysis of the Feminism in Pride and Prejudice
}

\author{
Xueqing Wang \\ Zhenjiang Watercraft College of PLA, Zhenjiang, China \\ Email: richerwang1980@yahoo.com.cn \\ Yan Liu \\ Zhenjiang Watercraft College of PLA, Zhenjiang, China
}

\begin{abstract}
This article is dedicated to the study of profound meaning underlying in the female social, psychological and sexual reality in the novel Pride and Prejudice in Victorian England. It explores into the heroine Elizabeth to study Austen's special perspective on feminism in the patriarchal society. In conclusion, this thesis examines the nature of Jane Austen's pioneering literary feminism, and both the positive and negative characterizations of Elizabeth in the text reveal the writer's feminist value in the Victorian England.
\end{abstract}

Index Terms - narrative perspective, feminism, narrative voice, female consciousness

\section{INTRODUCTION}

\section{A. Jane Austen and Her Life Time}

Among the distinguished English novelists of the $19^{\text {th }}$ century are several women. Women novelists began to appear in English during the second half of the $18^{\text {th }}$ century. But some gifted women of the $19^{\text {th }}$ century made such contributions to the development of the English novel that they have justifiably won their places in the front ranks of the brilliant realists headed by Dickens and Thackeray. Jane Austen is one of these remarkable women novelists.

Jane Austen, her life was, on the surface, even and serene, but her work reveals a mind of enormous vitality and scope, and a powerful understanding of human behavior. Born on December 16,1775, in the Hampshire village of Stevenson where her father was a clergyman, she grew up in an affectionate family, whose members were all great novel-readers. She was educated at home and began to wrote at an early age. There was a small table in the sitting room, on which she wrote her now famous novels including six complete ones and left behind three fragments. When a visitor entered, she would throw a sheet of paper or a piece of sewing over her work, and she modestly refused to acknowledge that she was the author of her novels, which were published anonymously owing to the prejudice prevailing at the time concerning the writing of novels by a lady. She never married, and she ignored literary circles, ridiculing the popular gothic novel and rejecting the tenets of Romanticism.

Among her six articles, pride and prejudice is the most widely read. Since its immediate success in 1813 , it has remained one of the most popular novels in the English language. Jane Austin called this brilliant work "her own darling child". Austin began to write it when she was 21.But the manuscript "went begging" for 16 years at the doors of publishers before it was published in1813.It is a story of young girl who rejects an offer of marriage because the young nobleman is rude to her family.

In the development of the entire world, there is a conception in human's mind for a very long time that man is a hero, a magnificent object to be admired. Woman only depends on man. So man will never admit woman' intellectual superiority, or even their equality and their possession of a normal human equipment of thought. This conception also has an effect on literature. In the long history of literature, man has taken relatively priority in this area. The readers ignore the books which were written by females. So these prejudices led many women to publish their first novel anonymously. There was no exception to Austen. Austen's first published novel, Sense and Sensibility appeared with the title page reading "By a Lady". And her second published novel Pride and Prejudice was published with "By the Author of Sense and Sensibility". They do have much faith that women are too naive and fool to create articles. They have incurable prejudice to the females. So in a very long time the English literature is filled in articles with male splendid writing ways. As a result, during the $18^{\text {th }}$ and $19^{\text {th }}$ century, there was almost none great articles created in England in such 40 years. However, there were a handful of remarkable women bringing us some monumental works. They used their special narrative perspective to describe story and describe characters. They told the whole world that women had a fine and fluent intelligence. In truth, women are not only intelligent, they have almost a monopoly of certain of the subtler and more utile forms of intelligence. It might be reasonable described as a special feminine character. So their judgment in many matters of capital concerns is more subtle and searching than men. They can see the actual things within. Women decide the larger questions of life correctly and quickly, not because they are lucky guessers, not because they are divinely inspired, not because they practice a magic inherited from savagery, but simply and solely because they have sense. They see at a glance what most men could not see with searchlights and telescopes; They are at grips with the essentials of a problem before men have finished debating its mere externals. They are the supreme realists of the race. They are the possessors of a rare and subtle super-logic. To my mind, Jane Austen was the 
outstanding writer among these remarkable female writers. She distinguished her writings from male ones. Her articles are in the foundation of her experiences. What she did was to bring her feminine sharpness of wit, and to bear upon her feminine clear-thinking. In a summary, western literary history is overwhelmingly male or, more accurately, patriarchal. People all assume that literature had to be male. So we can see woman writers doing this over and over again- they search for a female model not because they want dutifully their "feminity" but because they must legitimize their own rebellious endeavors. At the same time, like most women in patriarchal society, woman writers do experience the gender as a painful obstacle, or even a debilitating inadequacy. In other words, like most patriarchally conditioned women, they are victimized by the real condition. Thus the loneliness of the female artists, their feelings alienation from male predecessors coupled with their needs for sisterly precursors and successors, their urgent sense of her need for a female audience together with their fear of the antagonism of male readers, their culturally conditioned timidity about self-dramatization, their dread of the patriarchal authority of art, their anxiety about the impropriety of female invention-all these phenomena mark the woman writers' struggle for artistic self-definition and the differentiation of their efforts at self-creation from those of their male counterparts.

\section{B. Literature Review}

Jane Austen is now considered as one of the greatest writers in the world. But it is not a smooth process for her to get the well-deserved reputation and status. In the nearly two hundred years, Jane Austen and her novels still keep catching the attention of the critics. Charlotte Bronte once harshly criticized her novels, excluding her from the ranks of great authors because she thought that the passions were perfectly unknown to Jane Austen. Mrs. Browning stated that "Austen's characters had no souls and were lack of depth and width". In my viewpoint, such critics also made the value of Jane Austen known. As we all know, there are many people studying her novels in terms of dramatic effect ,the use of irony and the characterization. Austen's contribution to the English novel has also been studied. Of all the above mentioned aspects, the theme of marriage is mostly frequently discussed. All these researches make great contributions to the study on Jane Austen, However, there is no systematic research on Jane Austen's feminist narrative techniques in terms of feminist narratology. But recently, Austen's novels are analyzed more and more as products of a specific culture. The most outstanding new approach is the feminist critical theory. The first book devoted to Austen as a feminist is Margaret Kirkham's Jane Austen, Feminism and Fiction (1983), which argues that Austen dramatizes the concerns of feministic enlightenment of her day like Mary Wollstonecraft. Later there are more books on this topic. It is Susan S. Lanser who is the first to study Jane Austen by combining feminism and narratology. In her Fiction of Authority, Lanser makes an analysis on the implied women narrative voice and how narrative authority is established through the study of FID (free indirect discourse) in Jane Austen's novels. These studies show that Austen's feminine narration establishes the female writing style in English literature. Austen's feminine perspective of life and vocalization of growing female self-awareness, her power of consciousness though her unique narrative techniques.

\section{FEMINIST NARRATIVE IN AUSTEN’s NOVElS}

\section{A. The Theory of Feministic Narratology.}

Narratology started in the 1960's in France. As an extension of structuralism, it was introduced by Tzvetan Todorov in 1969. Feminist narratology has enjoyed a history of development of about twenty years in the west. The creator of feminist narratology, Susan S. Lanser, in the year 1981, first combined narratology research with feminism.

Feminist narratology aims at fighting for the equality between women and men and changing the social and literary status of women writers. The main task is to explore narrative discourse, structural features of works and narrative strategies and then to do research on gender politics under historical, social and cultural context. In Lanser's words, feminist narratology examines the role of gender in the construction of narrative theory. By this means, male writing styles and female writing styles can be distinguished so that sexual difference and discrimination can be exposed. Women novelists use different narrative forms from men novelists to establish their own narrative authority and their own literary tradition. This difference results from the social historical and cultural background: women's social status. In this sense, narrative discourse has social significance and political implications.

Basically, there are two levels of feminist narratology--story and discourse. At the level of story, feminist narratology focuses on differences in characters, events and contexts between women novelists and men novelists as well as social and historical reasons for the differences. According to the study of the feminist narratology, we know that .Feminist narratology mainly focuses on the level of discourse. In a word, feminist narratology is interested in how the women writers employ narrative strategies to claim their narrative authority.

\section{B. Feministic Strategies in Jane Austen's Novels}

As a female writer, Jane Austen began her own literary creation when consciousness of women was awakened gradually in the late 18th century. Austen cared about women's social position and claimed for women's right to work and attempted to seek for the value of women in society and her effort to subvert the male-dominated value system can be seen in her novels. Her feministic strategies are reflected in two ways, narrative content and characterization. In narrative content, Austen concentrates on women's routine life, love and marriage. She is at her best in writing about young girls, because she understands them astonishingly well. So she neglects the narrative modes used by male writers 
of her time who concerns much about important historical events. In characterization, Austen always makes the female figures main characters of her novel, and makes them the centers of the stage. She describes women as what they really are and advocates a new idea of love and marriage. With her sensible female narrative strategies, Austen effectively gets rid of the control of masculine discourse and establishes feminist narrative authority.

\section{The Feministic Point Of View In Austen’s Novels}

As we all know that the narrative perspective is a significant subject in the investigation of novels. Narrative perspective is not only the angle from which the narrator and the characters view the story, but also includes the perspective which the novelist takes in his creative process. It is argued that the narrative vision of Pride and Prejudice should be classified as non-focus. Because of this perspective can fix a bird's eye on all the novels, so it can unfold each kind of character's actions and considerations calmly. As a consequence, it manifests the main character's no sense of belonging and rootless condition to the greatest degree. This novels describes some big or small families as objects to narrate a common world. But if the narrator wants to make a smooth narration about this small world, or predict the destiny of the characters or stories, or make a psychological description in depth on many characters, then this perspective is the only one choice which the works must use to display all the things. Austen tells female experience from the heroines' point of view which turns female images into active observer so as to guarantee their female consciousness.

Different from her contemporary women writers, Austen does not passionately identify herself with any of her characters and none of her books are written in the first person. She gives her heroines an impersonal freedom. In her six completed novels, Austen focuses on intelligent young women, through whose eyes she presents women, men and the world. In Pride and Prejudice, Austen's earliest novel, the author narrates the story mostly from the eyes of Elizabeth. Everything we know is from the heroine's eyes, ears and mind. In this novel, the readers are almost led by the heroines from the beginning of the story. This kind of point of view is non-focus perspective, which presents the story from the internal perspective of a particular character, As the word itself suggests, a reflector reflects events of the outer world in his consciousness, perceives and feelings. All the heroines in Austen's novels are the focalizers of narration and they are also the reflectors, since the narrator lets them read and expose the maladies of the society. It is not until Austen that dramatic change has been made. Scholars term the third-person narration as one of Austen's innovation, which creates the illusion of entry into the consciousness of fictional characters. So the third-person point of view in Austen's novels guarantees the female consciousness and female identity since each heroine has the right to observe other characters. So as the scholar Jane Spencer points that, with the third-person point of view, "women writers were developing their own distinctive use of narrative voice".

In Austen's novels, usually a female character is focused on in two ways, i.e. the inside and the outside. The character is portrayed from the outside world, seen by an objective observer, and from the inside, through the character's own thoughts and memories. Such point of view enables the narrator to have a close relationship with the heroine so as to reveal the story's ideology effectively. It is not difficult for one to find Austen's subtle shift from omniscient to limited point of view in her novels. By using omniscient point of view, the narrator can tell the readers the thought of all the characters and can jump out of the characters' minds to describe them objectively. The narrator even intrude the story with personal opinion. This "all-knowing" narrator presents between the readers and the story and retains complete control over the narrative, but the omniscient narrator is not a character in the story and is not involved in the plot, which makes him unsuitable to describe the characters' inner feelings. The great advantage of the omniscient point of view is the flexibility it gives its "all-knowing" narrator, who can direct the reader's attention and control the sources of information. As the story goes, the narrator stands back from the events and limits her ability to penetrate the minds of characters by selecting a single character to act as the center of revelation, the story moves to the heroine's point of view. Thus, Austen successfully transits the role of female characters from being observed to observing others. It is a way of gradual disillusionment with the patriarchal ideology of gender and her steady movement toward a self-conscious female identity free from patriarchal society.

In Austen's later novels, the transition from omniscient to third-person point of view is more often used in a more subtle and mature way. Like in Pride and Prejudice, Austen begins to tell her story from an omniscient point of view, by which the narrator can tell the reader the thoughts of all the characters and can jump out of the characters' minds to describe them objectively. From chapter 10,much of the story is told from Elizabeth's perspective. The narrator stands back from the events and Elizabeth becomes the focus of the whole story. The reader observes and knows the events by what Elizabeth knows or sees. Her mind and eyes become the angle of view and the point of entrance for the reader to know about the story. Those gentlemen, wise or unwise, rich or poor, both act as the ornament of the story. By the change of narrative point of view, Elizabeth is no longer observed by others but an active observer. So women's marginal position is changed.

In this way, Austen has succeeded in her seamless movement from one point of view to another. As the point of view is shifted from the narrator to the heroine, the reader is quite intimate with the heroine. By narrating the stories from the omniscient point of view to feminist internal point of view which men novelists often fail to do, Austen let the female characters themselves read and expose the maladies of the society. This shift also gives the reader the opportunity to re-evaluate what he has already learned and to examine the heroine's ability to arrive at a critical assessment of the facts 
with which she is confronted.

\section{CONCLUSION}

This study aims at investigating the feminist narrative techniques used by Jane Austen. In order to show how Austen uses different narrative techniques to establish feminist authority and deconstruct the male consciousness. Different from the traditional male writing style, Austen regarded female as the center part of the novel. She let her female characters describe the story as their daily life, transmit the information to the readers. In her novels, the heroines are not traditional angles or monsters defined by male writers. All of them are independent. They are narrators rather than objects in traditional novels. .In this way, Austen successfully deconstructs the male's voice and establishes feminist narrative authority. Austen's writing itself is a rebellious act against the patriarchal rumor of the female intellectual inferiority and duping regulation of women's proper behaviors.

Jane Austen is a remarkable woman in the literary area. Her contribution to the literature is partly to a special writing style and partly establishes a new statue to women. She uses her special perspective of female to show that women is independent rather than dependent.

As a conclusion, Austen lived in her limited world with her family, so it seemed that she was not influenced by the changing society at all. Unlike other realists in the 19th century, she has never dealt with social problems and revolutions directly. There are neither heroic passions nor astounding adventures in Austen's novels. Living in the countryside all her life, she was good at describing the people around her. So in her novels, she created a lot of vivid characters of snobbish and arrogant squires. She satirized the snobbery, pride and vanity of the middle class people with humorous words. Apparently she wrote about everyday life, but in fact, some social problems were disclosed in her novels. Like other feminists, she cared about women's social position and claimed for women's right to work, and her point of view was reflected in her novels.

\section{REFERENCES}

[1] Cheshire Jenny. (1984). The Relationship between Language and Sex in English. London: Academic Press.

[2] Giles, Howard. (1977). Linguistic Sexism. Washington, D.C. University Press of America.

[3] H.L Mencken. (1922). In Desense of Women. New York: Alfred A. Knopf, Inc.

[4] Hauck, Maurice. (1995). Linguistics for English Learners. Princeton: Princeton University Press.

[5] Miraanda Fricker \& Jennifer Hornsby. (2000). The Cambridge Companion to Feminism in Philosophy. Cambridge University Press.

[6] Mish, Frederick C. (2003). Webster's Collegiate Dictionary. (11th ed). New York: Merriam-Webster.

[7] Nilsen Alleen Pace. (1990). Sexism in English: A 1990s Update. St. Martin's Press.

Xueqing Wang was born in Zhenjiang, China in 1980. She received her M.A. degree in Foreign Linguistics and Applied Linguistics ,Guangxi Normal University, China in 2009.

She is currently a lecturer in Department of Fundamental Course, Zhenjiang Watercraft College of PLA, Zhenjiang, China. Her research interests include Inercultural communication ;Second Language Acquisition and Foreign Language Teaching.

Yan Liu, was born in 1979, graduated from Katholieke Universiteit Leuven, faculty of psychology and educational sciences, granted by MA on social and cultural anthoropology in 2005, specialized in culture difference and comparison. Now working as teaching assistant in Zhenjiang Watercraft College. 